\title{
KONVERSI AGAMA DARI AGAMA HINDU KAHARINGAN \\ KE AGAMA KRISTEN DI DESA SAKAKAJANG \\ KEC. JABIREN RAYA KABUPATEN PULANG PISAU \\ Oleh
}

\author{
Ni Made Ratini
}

\begin{abstract}
ABSTRAK
Konversi agama adalah berpindahnya atau berubahnya keyakinan/ agama dari keyakinan/ agama yang sebelumnya dianut menuju keyakianan/ agama baru yang dianutnya. konversi agama yang dimaksud dalam penelitian ini adalah konversi agama dari Hindu Kaharingan ke agama Kristen pada masyarakat Hindu Kaharingan di desa Sakakajanga kecamatan Jabiren Raya Kabupaten Pulang Pisau. Penelitian ini berusaha mengungkap tentang fenomena perpindahan agama yang terjadi, apa faktor yang menyebabkan dan apa dampaknya dalam masyarakat.
\end{abstract}

Terjadinya Konversi Agama dari Hindu Kaharingan ke Kristen pada masyarakat Hindu Kaharingan di Desa Sakakajang disebabkan oleh (1) faktor pengetahuan agama Hindu Kaharingan yang kurang dipahami secara mendalam dalam diri seseorang sehingga mudah terpengaruh melakukan konversi Agama, (2) Faktor ekonomi yang kurang mencukupi kemudian ada yang menawarkan bantuan kemanusiaan sehingga mereka berpikir untuk mengubah dirinya ke arah kehidupan yang lebih baik, (3) Faktor Perkawinan untuk menyatukan agama ke dua calon mempelai yang tadinya berbeda, (4) Faktor Pendatang Pergaulan penduduk asli dengan pendatang mempunyai implikasi yang cukup tinggi terhadap pandangan dan pengetahuan bahkan $\mathrm{p}$ keyakianan agama, Sehingga dalam pergaulan itu mereka tertarik untuk melakukan konversi agama dari Hindu Kaharingan ke Kristen.

Dengan adanya konversi agama bagi masyarakat Hindu Kaharingan dari Hindu Kaharingan ke Kristen di Desa Sakakajang menimbulkan dampak Religius dan dampak sosial sehingga berkurangnya pemeluk agama Hindu Kaharingan dan tidak ada lagi kegiatan upacara/ ritual Agama Hindu Kaharingan bagi masyarakat Sakakajang.

Kata Kunci: Konversi agama Hindu Kaharingan ke Kristen

*Dosen pada Fakultas Dharma Sastra IAHN-TP Palangka Raya 


\section{PENDAHULUAN}

Indonesia terdiri dari berbagai suku bangsa dan tersebar di seluruh Wilayah Nusantara. Bangsa Indonesia memiliki beraneka ragam adat istiadat, tradisi, agama dan budaya yang menjadi kebanggaan bangsa Indonesia dan menggambarkan kekayaan budaya dan menjadi modal bagi pembangunan budaya bangsa. Seiring dengan perkembangan Ilmu pengetahuan dan Teknologi yang semakin pesat khususnya di bidang informasi dan komunikasi sehingga jarak antar bangsa, antar Negara, pulau di belahan bumi ini tidak menjadi rintangan. Dengan perkembangan tersebut menyebabkan perubahan yang signifikan terhadap pengaruh kebudayaan satu kelompok sosial terhadap kelompok-kelompok lain. Dengan adanya kontak-kontak antar kelompok melalui proses interaksi sosial tidak menutup kemungkinan antar kelompok mengadopsi kebudayaan tertentu bilamana kebudayaan itu berguna untuk mengatasi dan memenuhi berbagai tuntutan yang dihadapi.

Demikian juga dengan suku Dayak yang merupakan salah satu suku dari berbagai suku bangsa di Indonesia, di mana sebagian masyarakatnya menganut Agama Hindu Kaharingan. Dalam menjalani kehidupan mereka saling berinteraksi antara yang satu dengan yang lainnya. Mereka tidak mungkin bisa hidup sendiri tanpa bantuan orang lain, ia memerlukan kelompok, memerlukan kebersamaan dalam masyarakat. Masyarakat akan bisa berjalan dengan baik apabila dalam menjalankan hidupnya berdasarkan pada ajaran agama yang dianutnya, dan bersikap dalam masyarakat berdasarkan adat istiadat dan budaya yang berlaku.

Seiring dengan perkembangan jaman dan pengaruh global seperti sekarang ini akan berdampak luas kepada kehidupan manusia, baik 
kehidupan masyarakat perkotaan maupun masyarakat pedesaan, demikian juga perkembangan keagamaan umat beragama mengalami pasang surut. Seperti yang terjadi pada masyarakat Hindu Kaharingan di Desa Sakakajang Kecamatan Jabiren Raya Kabupaten Pulang Pisau. Sesuai hasil wawancara dengan Sudir Tokoh Masyarakat Desa Sakakajang bahwa sebelum Tahun 1935 Masyarakat Desa Sakakajang mayoritas beragama Hindu Kaharingan. Tahun 1935 menurut penuturan mereka datang penyebar agama Kristen (Misionaris) dari Banjarmasin ke Pulang Pisau akhirnya sampai ke desa Sakakajang. Dengan kedatangan Misionaris di Desa Sakakajng mempengaruhi masyarakat Hindu Kaharingan dengan bentuk wacana bahwa Tuhan Yesus dapat menghapus dosa orang tersesat, Tuhan Yesus dapat mengantarkan Roh Masuk Surga, wacana bantuan kemanusiaan dengan mendatangi orang yang tidak mampu diberikan bantuan Sembako, bantuan obat-obatan, bantuan pendidikan. Dengan adanya pengaruh dan pandangan seperti di atas menyebabkan masyarakat Hindu Kaharingan yang kurang memahami ajaran agama Hindu Kaharingan secara utuh, mudah tergugah hatinya untuk melaksanakan konversi agama dari Hindu Kaharingan ke agama Kristen. Menurut Penuturan (Sudir) Mereka melaksanakan konversi agama dari Hindu Kaharingan ke Kristen alasannya karena agama kristen cara beragama lebih simpel tidak memakai waktu lama dan biaya yang dikeluarkan tidak banyak Seperti Hindu Kaharingan melaksanakan Upacara Tiwah dengan biaya yang besar (wawancara tanggal 4 September 2015).

Sesuai hasil wawancara peneliti dengan (Suliwatie, tanggal 5 september 2015) guru agama Hindu di Desa Sakakajang kebetulan rumahnya tetangga dengan gereja, beliau mengatakan bahwa tahun 1985 masih banyak yang menganut agama Hindu Kaharingan namun satu 
persatu masyarakat Hindu Kaharingan berpindah agama ke Kristen. Akhirnya berdampak kepada berkurangnya pemeluk agama Hindu Kaharingan di Desa Sakakajang. Masyarakat Desa Sakakajang yang masih memeluk agama Hindu Kaharingan desa Sakakajng berjumlah 12 orang. Dan berdampak juga terhadap berkurangnya pelaksanaan kegiatan keagamaan Hindu Kaharingan yang telah diwariskan oleh leluhur mereka sejak jaman dulu.

\section{PEMBAHASAN}

\section{A. Pengertian Konversi Agama}

Konversi agama merupakan suatu peristiwa penting dalam kehidupan seseorang. Keputusan melakukan konversi agama merupakan keputusan besar dengan konsekuensi yang besar pula. Konversi agama akan membuat seluruh kehidupan seseorang berubah selama-lamanya, karena pada dasarnya konversi agama merupakan perubahan mendasar dan penataan ulang identitas diri, makna hidup juga aktivitas seseorang. Peristiwa konversi agama tidak hanya membawa konsekuensi personal tapi juga reaksi sosial yang bermacam-macam, terutama dari pihak keluarga dan komunitas terdekat.

Sebelum lebih jauh mengkaji tentang konversi agama terlebih hulu kita pahami tentang pengertian konversi. Pengertian konversi agama secara etimologi konversi berasal dari kata latin "conversio" yang berarti tobat, pindah, berubah agama (DepdikBud, 2001:592).

Selanjutnya kata tersebut dipakai dalam kosakata Inggris "conversion" yang mengandung pengertian: berubah dari suatu keadaan, atau dari suatu agama ke agama lain (Jalaluddin, 2011: 361). 
Berdasarkan arti kata-kata tersebut maka konversi agama mengandung pengertian: bertobat, berubah agama, berbalik pendirian (berlawanan arah) terhadap ajaran agama yang dianutnya atau masuk ke dalam agama baru.

Menurut Max Heirich (dalam Jalaluddin 2011: 362) mengatakan bahwa konversi agama secara terminologi merupakan suatu tindakan di mana seseorang atau sekelompok orang masuk atau berpindah kesuatu sistem kepercayaan atau perilaku yang berlawanan dengan kepercayaan sebelumnya.

Sedangkan pengertian agama menurut (Anwar, 2005: 49) menyatakan agama adalah kepercayaan kepada Tuhan yang memiliki kekuatan kodrat yang maha mengatasi, menguasai, menciptakan alam semesta dan telah menganugrahkan kepada menusia watak sehingga manusia dapat hidup. Agama mempunyai peranan penting bagi kehidupan manusia karena agama menuntun kehidupan manusia ke jalan yang lebih baik (Ali, 1965:6).

Konversi agama secara umum dapat diartikan berpindah atau berubah agama dari agama yang sebelumnya dianut ke agama baru yang dianutnya. Berdasarkan beberapa pendapat tentang konversi agama di atas maka konversi agama yang dimaksud dalam penelitian ini yang terjadi di desa Sakakajang adalah konversi agama dari Hindu Kaharingan ke Kristen.

\section{B. Terjadinya Konversi Agama dari Hindu Kaharingan ke Kristen pada masyarakat Hindu Kaharingan di Desa Sakakajang.}

Berdasarkan hasil penelitian yang peneliti lakukan di Desa Sakakajng bahwa terjadinya konversi agama sudah tentu disebabkan oleh 
berbagai faktor baik faktor dalam diri sendiri maupun faktor dari luar diri manusia. Adapun faktor-faktor yang menyebabkan konversi agama adalah sebagai berikut:

\section{Faktor Pengetahuan}

Penyebab terjadinya konversi agama dari Hindu Kaharingan ke kristen di desa Sakakajang disebabkan karena pengetahuan agama Hindu Kaharingan yang kurang dipahami secara mendalam dalam diri seseorang. Padahal pemahaman ajaran Agama yang matang merupakan pondasi utama dalam iman seseorang ketika akal pikiran menjadi penentu dalam hidupnya manusia. Pengetahuan nilai-nilai agama Hindu Kaharingan yang diturunkan oleh Ranying Hatalla Langit, kepada Raja Bunu untuk dipelajari secara turun temurun oleh anak cucunya, yang disebut dengan masyarakat Hindu Kaharingan yang diwariskan kepadanya belum dihayati, diamalkan, belum menyatu dalam jiwa pikiran dan tindakan. Jika kegiatan upacara agama Hindu Kaharingan dilaksanakan semata-mata atas dasar menghormati leluhurnya. Masalah kurangnya pemahaman ajaran agama nilai-nilai agama yang menyebabkan terjadinya penurunan kepercayaan karena tidak ada pembentengan diri dalam menghayati ajaran agama. Pengetahuan ajaran Agama Hindu Kaharingan hanya dipelajari secara tradisional, artinya tidak mendapatkan proses pembelajaran dan pendidikan yang baik.

Menurut Tanduk, mengatakan bahwa perpindahan agama yang saya lakukan dari agama Hindu Kaharingan ke Kristen karena kurangnya pemahaman atau pengetahuan saya tentang agama Hindu Kaharingan walaupun sadar bahwa itu adalah agama leluhur, di samping itu juga jarang mendapat pembinaan dari lembaga Hindu Kaharingan dan tidak mendapat proses pembelajaran serta pendidikan yang baik (Wawancara,5 September 2015). sesuai pernyataan tersebut di atas karena kurangnya 
pengetahuan, pemahaman, nilai-nilai agama dalam diri manusia khususnya umat Hindu Kaharingan di Desa Sakakajang ketika itu, maka dalam dirinya terjadi satu konflik atau masalah yang menyebabkan kebimbangan kepercayaan sehingga mereka melakukan konversi agama dari Hindu Kaharingan ke kristen.

\section{Faktor ekonomi}

Faktor Ekonomi menjadi salah satu penyebab seseorang atau sekelompok orang ingin beralih menjadi pemeluk Kristen. Ekonomi dalam kehidupan manusia mempunyai peran penting dan bahkan sebagian besar orang menjadi tolak ukur keberhasilan. Bahkan masyarakat Indonesia memandang ekonomi sebagai kunci kesuksesan dalam bekerja, karena semua orang bekerja untuk mencari harta benda atau ekonomi untuk mencukupi kebutuhan hidupnya. Jika seseorang yang tidak mencukupi kebutuhan ekonominya dalam kehidupan seharihari orang tersebut bisa digolongkan masyarakat miskin. Ekonomi yang dibutuhkan dalam sepanjang hidupnya dihasilkan dari bekerja sebagai pegawai, buruh, swasta bahkan ada yang menjadi pemulung.

Ekonomi Masyarakat menjadi simbol kejayaan, kebaikan, perkembangan dan kemajuan, tetapi ekonomi juga yang akan menjatuhkan harkat dan martabat manusia. Tercukupi ekonomi masyarakat maka masyarakat itu akan menjadi sejahtera. Sebaliknya bila ekonomi tidak mencukupi maka kehidupan masyarakat itu akan menderita, sehingga menimbulkan konflik dalam dirinya disebabkan oleh ekonomi yang kurang memadai. Sehingga muncul pemikiran untuk melakukan konversi agama. Menurut (Efendi), menyatakan bahwa banyak terjadi perpindahan agama yang dulunya beragama Hindu Kaharingan pindah ke agama Kristen di Desa Sakakajang karena faktor ekonomi yang kurang mampu. Karena ekonominya kurang mencukupi 
kemudian ada yang menawarkan memberi bantuan ekonomi maka spontan saja orang menerima dan terus akhirnya pindah agama karena ada rasa balas budi dan perasaan yang tidak enak (Efendi, wawancara tanggal 5 September 2015).

Perpindahan agama Menurut (tanduk) menyatakan salah satu faktor penyebab pindah agama adalah kemiskinan. Karena kemiskinan yang terjadi orang berpikir untuk mengubah dirinya ke arah kehidupan yang lebih baik terutama pindah agama. Faktor kemiskinan menyebabkan lemahnya keimanan Masyarakat Hindu Kaharingan sehingga memutuskan untuk pindah ke agama kristen yang lebih menjanjikan kehidupan ekonomi yang lebih baik. Konflik dalam dirinya dan masalah ekonomi mempunyai dampak terhadap kepercayaan atau agama yang menjadi pengisi jiwa dalam kekosongan untuk memuja Tuhan. Lebih lanjut (Sudir) menyatakan bahwa konversi agama pada Masyarakat Hindu Kaharingan ke kristen disebabkan oleh kegiatan cara beragama Hindu Kaharingan rumit menggunakan waktu lama dan mengeluarkan biaya yang banyak seperti pada kegiatan Upacara Tiwah, (Sudir, wawancara tanggal 4 September 2015).

Berdasarkan beberapa pendapat tersebut di atas bahwa faktor kemiskinan menjadi penyebab terjadinya konversi agama.

\section{Faktor perkawinan}

Faktor perkawinan menjadi faktor yang paling dominan terjadinya konversi agama pada masyarakat Hindu Kaharingan. Konversi Agama yang disebabkan oleh perkawinan sering terjadi dalam kehidupan masyarakat yang akan melangsungkan perkawinan. Dari hasil wawancara peneliti dengan (Sipet, tanggal 5 September 2015) menyatakan konversi agama terjadi ketika seseorang ingin menikah dan calon istri atau calon suami bukan beragama Hindu Kaharingan. Dalam keadaan seperti itu 
pasti calon pengantin mengalami kebingungan tentang agama apa yang akan dianutnya. Kecenderungan pindah agama mengikuti agama calon suami atau agama calon istrinya, menjadi keputusan akhir di tengah kebingungan masyarakat Hindu Kaharingan ketika dihadapkan pada pilihan antara ia tetap bertahan pada agama Hindu Kaharingan atau ia harus konversi agama ikut agama Suami atau agama Istri. Seseorang yang telah mengalami perubahan status karena perkawinan banyak mempengaruhi kehidupan seseorang, perubahan status tersebut berlangsung secara mendadak. Lebih lanjut (Sipet) menyatakan bahwa konversi terjadi pada masyarakat Hindu Kaharingan di Desa Sakakajang disebabkan karena calon pengantin yang akan melangsungkan pernikahan masih menganut agama yang berbeda karena syarat perkawinan harus beragama yang sama sehingga salah satu harus melaksanakan konversi. Perkawinan yang terjadi karena perbedaan agama, yang akan konversi ke salah satu agama yang lebih kuat pengaruhnya ditinjau dari faktor pengetahuan, pekerjaan, keturunan dan status sosial di masyarakat. Namun Konversi agama yang terjadi di Desa Sakakajang tidak menjadi masalah dalam kehidupan beragama, karena adanya kesadaran untuk mengikuti agama suami atau mengikuti agama istri. Berdasarkan keterangan di atas maka penyebab terjadinya konversi agama dari Hindu Kaharingan ke Kristen pada Masyarakakat Hindu Kaharingan di Desa Sakakajng karena adanya perkawinan.

\section{Faktor pendatang}

Terjadinya konversi agama atau perpindahan agama dari Hindu Kaharingan ke Kristen, selain dipengaruhi dari faktor dalam diri juga dipengaruhi oleh faktor ekstern/ lingkungan sosial masyarakat desa Sakakajang. Lingkungan sosial merupakan salah satu faktor pendorong terhadap pola keagamaan seseorang, sebab kondisi masyarakat yang 
teratur, tertib akan mempengaruhi kondisi kehidupan beragama seseorang ( Suasti dan Suastawa, 2008:78).

Berdasarkan uraian di atas lingkungan sosial memberi peluang besar terjadinya konversi agama. Perkembangan ilmu pengetahuan dan teknologi yang semakin pesat, jumlah penduduk semakin banyak dan persaingan kehidupan semakin menglobal termasuk persaingan jumlah pemeluk agama yang terjadi sejak dulu hingga sekarang. Disadari atau tidak persaingan antara pemeluk agama yang terjadi di Kabupaten Pulang Pisau khususnya di Desa Sakakajang. Persaingan dan perebutan kekuasaan dan keimanan telah merajalela memasuki relung kehidupan manusia. Berkembangnya manajemen organisasi dan ditambah dengan keahlian dalam berbicara pemimpin dan mengorganisasikan masyarakat agama Kristen dan islam berkembang pesat dapat masuk ke pedalaman pada masyarakat Dayak Kalimantan tengah khususnya di desa Sakakajang Kecamatan Jabiren Raya Kabupaten Pulang pisau. Masyarakat Dayak yang dulunya menganut agama leluhur yaitu agama Hindu Kaharingan karena mereka kurang memahami ajaran agama Hindu Kaharingan secara mendalam sehingga mudah tergoda oleh para pendatang yang menyebarkan misi agama kristen dengan cara memberi bantuan Sembako, bantuan pendidikan, bantuan kesehatan dan dengan menawarkan masuk surga. Sehingga Umat hindu Kaharingan merasa tergugah untuk melakukan konversi agama. Sesuai perjalanan waktu yang telah mengalami perubahan pola pikir masyarakat, apalagi dibarengi dengan adanya gerakan Misionaris dan masyarakat pendatang yang tinggal di desa Sakakajang secara langsung atau tidak langsung akan mempengaruhi kehidupan desa Sakakajang, khususnya dalam bidang beragama. Pergaulan penduduk asli dengan pendatang mempunyai implikasi yang cukup tinggi terhadap pandangan dan 
pengetahuan bahkan terhadap kepercayaan agama. Perubahan kehidupan masyaraka terjadi karena adanya akulturasi budaya antara penduduk asli desa sakakajang dengan penduduk pendatang. Sehingga dalam pergaulan itu mereka tertarik untuk melakukan konversi agama dari Hindu Kaharingan ke Kristen.

\section{Dampak Konversi Agama Dari Hindu Kaharingan ke Kristen pada masyarakat Hindu Kaharingan di Desa Sakakajang.}

Dengan adanya konversi agama bagi masyarakat Hindu Kaharingan dari Hindu Kaharingan ke Kristen di Desa Sakakajang menimbulkan berbagai macam dampak bagi masyarakat Sakakajang. Berbagai dampak dimaksud adalah:

\section{Dampak Religius}

Dengan adanya konversi agama dari agama Hindu Kaharingan ke Kristen di desa Sakakajang Kecamatan Jabiren Raya Kabupaten Pulang Pisau akan Berdampak kepada:

a. Jumlah umat Hindu Kaharingan di daerah ini semakin berkurang bahkan yang masih beragama Hindu Kaharingan saat peneliti turun ke Desa Sakakajang hanya berjumlah 12 orang.

b. kegiatan upacara/ ritual agama Hindu Kaharingan yang diwariskan oleh leluhur mereka jarang dilaksanakan bahkan tidak ada lagi semaraknya kegiatan upacara Tiwah. Sesuai pernyataan Sudir yang peneliti wawancarai tanggal 4 September 2015 menyatakan bahwa : "Karena dia, bapak, ibu, saudara dan anak-anaknya sudah semua bergama Kristen sehingga kakek dan kakak kandungnya yang semasa hidupnya beragama Hindu Kaharingan meninggal 53 tahun yang lalu belum ditiwahkan. Bahkan beliau berpesan kepada peneliti bila ada yang melaksanakan upacara Tiwah masal di Palangka Raya agar 
peneliti menghubungi beliau karena mereka akan ikut meniwahkan kakek dan kakaknya yang sudah puluhan tahun meninggal.

c. Tidak ada lagi kegiatan upacara Mamapas Lewu di Desa Sakakajang Di Samping berdampak kepada kegiatan upacara Tiwah juga berdampak kepada kegiatan upacara mamapas Lewu di desa Sakakajang. Sesuai penuturan Sudir selaku tokoh masyarakat Desa Sakakajng mengatakan bahwa: "karena tidak ada lagi dilaksanakan upacara Mamapas Lewu di desa sakakajang berdampak kepada sering terjadi musibah yang menimbulkan korban jiwa yang menimpa masyarakat, Karena seringnya terjadi kecelakaan di desa sakakajang maka timbul keinginan dari masyarakat untuk melaksanakan upacara Mamapas Lewu, walaupun mereka sudah pindah keyakinan ke agama lain, namun mereka masih tetap percaya bahwa dengan melaksanakan kegiatan Ritual Mamapas Lewu akan berdampak kepada keselamatan bagi masyarakat. Di Desa Sakakajang tidak ada lagi Rohaniwan Hindu Kaharingan untuk memimpin Upacara mamapas Lewu dengan demikian akhirnya mereka mencari pemimpin upacara (basir) dari desa tetangga yaitu dari desa Mintin untuk menyelesaikan upacara tersebut. Sejak dilaksanakan upacara Mamapas Lewu sampai peneliti turun ke lapangan sesuai penuturan (Sudir, 4 Sepetember 2015) tidak pernah lagi ada musibah di Desa Sakakajang. Dari uraian di atas maka dengan adanya konversi agama berdampak kepada Umat Hindu Kaharingan semakin berkurang, tidak ada lagi ritual keagamaan Hindu Kaharingan di desa Sakakajang yang merupakan warisan leluhur mereka yang seharusnya dilestarikan.

\section{Dampak sosial}

Dengan adanya konversi agama dari agama Hindu Kaharingan ke Kristen di desa Sakakajang Kecamatan Jabiren Raya Kabupaten Pulang 
Pisau akan Berdampak kepada perubahan sosial kemasyarakatan. Namun perubahan juga mungkin mencakup keseluruhan aspek sistem yang menghasilkan perubahan yang menyeluruh dan menciptakan sistem baru yang secara mendasar berbeda dari sistem yang lama ( Salam, 2007: 2-3 dalam Surpi Aryadharma, 2011:21).

Berdasarkan hasil wawancara dengan sudir dampak sosial yang terjadi akibat konversi agama adalah:

a. Trasa asing di komunitas agama yang baru

b. Pada awalnya merasa dikucilkan / konfik dengan keluarganya namun seiring berjalannya waktu mereka saling menyadari dan rukun kembali.

c. Menjadi perbincangan masyarakat di desa sakakajang (Wawancara tanggal 4 September 2015).

Konversi yang terjadi pada kelompok atau individu tertentu secara perlahan menyeluruh pada sistim sosial. Akan tetapi adanya perpindahan ikatan individu atau kelompok dari masyarakat Hindu Kaharingan menuju pada komunitas kristen yang berbasis pada gereja, tentu saja menimbulkan dampak terjadinya perubahan sosial kemasyarakatan.

\section{PENUTUP}

Berdasarkan uraian di atas dapat disimpulkan sebagai berikut: Konversi agama adalah berpindahnya atau berubahnya keyakinan/ agama dari keyakinan/ agama yang sebelumnya dianut menuju keyakianan/ agama baru yang dianutnya. Terjadinya konversi agama disebabkan oleh faktor pengetahuan tentang ajaran agama Hindu Kaharingan belum dipahami secara mendalam sehingga menganggap agama lain itu lebih baik dari agamanya sendiri, faktor kemiskinan juga sebagai pemicu orang 
berpikir untuk mengubah dirinya ke arah kehidupan yang lebih baik terutama pindah agama, faktor perkawinan untuk menyatukan agama dalam mahligai rumah tangga sebagai faktor konversi agama, dan faktor pendatang memberi pengaruh besar terhadap konversi agama terutama kaum misionaris yang hidup berbaur dengan lingkungan sosial masyarakat di desa Sakakajang.

Dengan adanya Konversi Agama Dari Hindu Kaharingan ke Kristen pada masyarakat Hindu Kaharingan di Desa Sakakajang menimbulkan dampak Jumlah umat Hindu Kaharingan di daerah ini semakin berkurang. Tidak ada lagi semaraknya kegiatan upacara/ ritual agama Hindu Kaharingan yang diwariskan oleh leluhur mereka, Konversi yang terjadi di desa Sakakajang juga berdampak sosial pada kelompok atau individu tertentu dengan adanya perpindahan ikatan individu atau kelompok dari masyarakat Hindu Kaharingan menuju pada komunitas kristen yang berbasis pada gereja, tentu saja menimbulkan terjadinya perubahan sosial kemasyarakatan.

\section{DAFTAR PUSTAKA}

Ali T.Hasan. 1965. Perbandingan Agama. Yogyakarta ; Al-Fatah

Anwar Ali dan Teno TP. 2005. Ilmu Perbandingan Agama dan Filsafat. Bandung: Pustaka Setia

Aryadharma, Ni Kadek Surpi. 2011.Membedah Kasus Konversi agama di Bali, Kronologi, Metode Misi dan Alasan di Balik Tindakan Konversi Agama dari Hindu ke Kristen dan Katolik di Bali serta Pernak-Pernik Keagamaan di Dunia. Surabaya: Paramita.

Azwar, Saifuddin. 2010. Metode Penelitian. Yogyakarta : Pustaka Pelajar

Departemen Pendidikan dan Kebudayaan. 2001. Kamus besar Bahasa Indonesia. Jakarta; Balai Pustaka.

Jalaluddin.H. 2011. Psikologi Agama, Jakarta: PT RajaGrafindo Persada. 
Suasti dan Suastawa, 2008. Psikologi Agama Sembangkan pikiran, Jiwa dan Raga, Denpasar; Widya Dharma. 